\title{
PENGEMBANGAN MEDIA PEMBELAJARAN BERBASIS MACROMEDIA FLASH
}

\author{
Hilda Handayani ${ }^{1}$ Yetri² $^{2}$ Fredi Ganda Putra ${ }^{3}$ \\ 123 Universitas Islam Negeri Raden Intan Lampung, Bandar Lampung, Indonesia \\ 1hildahandayani53@gmail.com
}

\begin{abstract}
Abstrak
Penelitian ini bertujuan untuk mengembangkan media pembelajaran melalui software program Macromedia Flash pada materi bangun ruang untuk menguji kelayakan media yang dikembangkan melalui ahli media, Ahli materi, Ahli bahasa dan respon Peserta Didik terhadap media pembelajaran. Jenis penelitian ini adalah penelitian dan pengembangan dengan menggunakan prosedur dari metode ADDIE yang merupakan singkatan dari Analysis, Design, Development or Production, Implementation or Delivery and Evaluations. Hasil penelitian yang diperoleh antara lain media pembelajaran berbasis Macromedia Flash, serta hasil penilaian para Ahli media pembelajaran berdasarkan hasil angket Ahli media, Ahli materi dan Ahli bahasa media pembelajaran yang dikembangkan dengan 2 kali tahap validasi. Validasi akhir dari Ahli materi mencapai skor rata-rata 3,5 Ahli media 3,3 dan ahli bahasa mencapai skor rata-rata 4 maka dapat disimpulkan media yang dikembangakan valid dan layak digunakan sebagai media pembelajaran. Setelah itu dilakukan uji coba lapangan, berdasarkan hasil analisis angket respon peserta didik pada uji skala kecil memperoleh skor 3,68 dan pada uji coba lapangan memperoleh skor 3,51 maka dapat disimpulkan kemenarikan media pada kategaori sangat menarik. Berdasarkan semua ini, maka dapat disimpulkan bahwa media tersebut layak dan dapat digunakan sebagai media pembelajaran.
\end{abstract}

Kata kunci:,Macromedia Flash; Media Pembelajaran; Pembelajaran Matematika;

\begin{abstract}
This study aims to develop the learning media through Macromedia Flash program software on building materials to test the feasibility of media developed through media experts, material experts, language experts and the response of learners to the learning media. This research type is research and development by using the procedure from the ADDIE method which stands for Analysis, Design, Development or Production, Implementation or Delivery, and Evaluations. The results obtained are Macromedia Flash-based learning media, as well as the results of the assessment of the media of learning based on the questionnaire. Media experts, material experts, and language linguists developed with two validation stages. The final validation of the Expert material reached an average score of 3.5 Experts 3.3 media and the linguist reached an average score of 4 it can be concluded that developed media valid and fit for use as
\end{abstract}


a medium of learning. After that field experiment, based on the results of the questionnaire responses of learners on a small scale test scored 3.68 and on field trials scored 3.51, it can be concluded that the interest level of the media is on the category of very interesting. Based on all this, it can be concluded that the media is feasible and can be used as a medium of learning.

Keywords: Macromedia Flash; Intructional Media; Mathematics Learning

\section{PENDAHULUAN}

Menurut Permendiknas Nomer 20 Tahun 2006 salah satu tujuan pembelajaran matematika adalah mengkomunikasikan gagasan dengan simbol, tabel, diagram, atau media lainnya untuk memperjelas masalah matematika (Ismaimuza, 2017; Putra, 2016). Pendidik mampu merancang pembelajaran yang memberikan kesempatan kepada peserta didik untuk aktif berinteraksi, berkomunikasi baik dengan sesama peserta didik atau dengan pendidik. Berdasarkan hasil pra penelitian yang dilakukan salah satu data menunjukkan masih rendahnya prestasi belajar matematika.

Permasalahan pertama peserta didik merasa kesulitan dalam menyerap materi yang disampaikan oleh pendidik dikarenakan media pembelajaran juga masih terbatas pada buku yang penyajian materinya padat dan tampilannya tidak menarik, serta banyaknya soal-soal dan tugas yang diberikan pendidik sehingga membuat peserta didik bosan untuk mempelajarinya. Peserta didik mengharapkan pendidik untuk memberi suasana kelas yang menarik agar peserta didik tidak bosan dan jenuh dalam proses belajar matematika. Peneliti juga melakukan wawancara dengan guru matematika dengan hasil wawancara bahwa hasil belajar matematika peserta didik sudah baik, tingkat pemahaman peserta didik juga sudah baik. Metode pembelajaran Matematika menggunakan metode konvensional yaitu dengan cara metode ceramah, mengerjakan soal-soal latihan selanjutnya diadakan tugas pekerjaan rumah sebagai bahan belajar dirumah. Selain itu Pengajarannya yang dilakukan hanya menggunakan buku ajar yang tersedia dari pemerintah dan peserta didik harus patut mempunyai buku itu juga sebagai bahan pegangan peserta 
Handayani, H., Putra, F., \& Yetri, Y. (2018). PENGEMBANGAN MEDIA PEMBELAJARAN BERBASIS MACROMEDIA

FLASH. Jurnal Tatsqif, 16(2). Retrieved from http://journal.uinmataram.ac.id/

index.php/tatsqif/article/view/160

didik untuk belajar mandiri baik dalam saat pengajaran berlangsung maupun diluar pengajarannya. Selain itu keterbatasan menggunakan komputer dalam membuat media pembelajaran matematika. Setiap peserta didik memang memiliki tingkat kesulitan yang berbeda-beda dalam memahami materi karna setiap peserta didik memiliki karateristik yang berbeda-beda pula. Salah satu hal ini yang menyebabkan peserta didik beranggapan pembelajaran matematika itu penuh dengan pengerjaan tugas dan membosankan, karna selalu berkutat dengan kegiatan seperti itu setiap pertemuan jam pelajaran, maka dari itu perlu adanya suatu pengembangan bahan ajar berupa media pembelajaran.

Media pembelajaran adalah alat bantu pada proses pembelajaran dalam rangka komunikasi antara pendidik dan peserta didik untuk membawa informasi berupa materi ajar sehingga peserta didik menjadi lebih tertarik untuk mengikuti kegiatan pembelajaran(Netriwati \& Sri Lena, 2017). Media pembelajaran juga memiliki kontribusi dalam meningkatkan mutu dan kualitas pembelajaran(Khairani \& Febrinal, 2016).

Perkembangan teknologi komputer yang semakin maju menuntut pendidik untuk mengikuti perkembangan teknologi dalam proses belajar dan mengajar, banyak sekali aplikasi-aplikasi komputer yang diluncurkan seperti Geogebra, Microsoft Powerpoint, Mathemathica 7, Adobe Flash, Macromedia Flash, dll yang seharusnya sudah bisa dimanfaatkan oleh para pendidik di indonesia untuk mengembangkan sebagai bahan ajar khususnya dalam pembelajaran matematika, metode konvensional dirasa sudah tidak relevan lagi digunakan. Oleh karena itu, pendekatan dengan metode konvensional sudah tidak lagi sesuai dengan perkembangan yang dihadapi oleh sekolah(Amalana, 2015).

Meskupun demikian, penggunana teknologi dapat juga berdampak negatif jika tidak dilakukan dengan tepat guna. Terkait dengan hal ini, Putrawangsa \& Hasanah (2018) menegaskan bahwa prinsip dasar dalam penggunaan teknologi digital dalam pembelajaran, khususnya dalam 
Handayani, H., Putra, F., \& Yetri, Y. (2018). PENGEMBANGAN MEDIA PEMBELAJARAN BERBASIS MACROMEDIA

FLASH. Jurnal Tatsqif, 16(2). Retrieved from http://journal.uinmataram.ac.id/

index.php/tatsqif/article/view/160

pembelajaran matematika, adalah teknologi tidak digunakan sebagai pengganti penggunaan pemahaman konseptual dan intuisi bermatematika, akan tetapi sebaliknya teknologi berperan untuk meningkatkan pemahaman konseptual siswa tentang ide matematika dan juga mengembangkan kemampuan intuisi siswa dalam bermatematika.

Metode Pembelajaran dengan menggunakan media komputer dapat merangsang peserta didik untuk mengerjakan latihan, melakukan kegiatan simulasi karena tersedianya animasi grafik, warna, dan musik(Lestari \& Istiqomah, 2017). Komputer juga dapat mengakomodasi peserta didik yang lamban dalam menerima pelajaran, karena ia dapat memberikan iklim yang lebih bersifat afektif, sehingga peserta didik tidak mudah lupa, tidak mudah bosan dan lebih sabar dalam menjalankan instruksi seperti yang diinginkan program(Hendra, 2017). Terkait dengan banyaknya aplikasi-aplikasi yang telah ada pada saat ini dan masalah-masalah di atas peneliti tertarik untuk memanfaatkan dan mengembangkan salah satu software untuk membuat media pembelajaran sebagai bahan ajar yang digunakan agar peserta didik lebih tertarik dan mudah memahami materi yang ingin disampaikan. Software yang dikembangkan peneliti adalah Macromedia Flash dikarnakan software ini menarik minat peserta didik belajar dengan tampilan gambar untuk penyajian materi dengan jelas, suara, dan animasi yang menarik.

Macromedia flash adalah software yang tepat untuk membuat sajian visual yang dapat menginterprestasikan berbagai media, seperti video, animasi, gambar dan suara untuk menarik minat dan komunikasi matematika peserta didik agar lebih mudah memahami, mengingat materi yang diajarkan, serta menjawab soal-soal latihan sebagai pemantapan pemahaman materi(Setiawan, Corebima, \& Zubaidah, 2013). Media ini digunakan agar peserta didik dapat melihat langsung simulasi dan demonstrasi yang menyerupai kejadian sebenarnya, serta dapat diterapkan dalam kehidupan sehari-hari. Macromedia Flash adalah program untuk membuat animasi dan aplikasi web professional. Bukan hanya itu, Macromedia Flash juga banyak 
digunakan untuk membuat game, animasi kartun, dan apilkasi multimedia interaktif seperti demo produk(Masykur, Nofrizal, \& Syazali, 2017).

Berdasarkan uraian di atas penulis tertarik untuk melakukan "Pengembangan Media Pembelajaran Matematika Berbasis Program Flash pada Materi Bangun Ruang Sisi Datar untuk Siswa SMP Kelas VIII". Mengembangakan aplikasi macromedia flash sebelumnya pernah dilakukan oleh beberapa peneliti yang menunjukan hasil bisa sebagai salah satu alat bantu dalam pembelajaran matematika untuk mengatasi kejenuhan peserta didik didalam kelas(Masykur, Nofrizal, \& Syazali, 2017). Peneliti yang lain juga menyatakan bahwa menggunakan media pembelajaran berbantuan macromedia flash hasilnya efektif, praktis, mudah dipahami dan valid(Nugroho, Putra, Putra, \& Syazali, 2017). Perbedaan dari penelitian ini adalah pada materi yang disajikan dan pada hasilnya untuk melihat respon peserta didik terhadap penggunaan media pembelajaran.

\section{LANDASAN TEORI}

Dalam pengembangan media pembelajaran ini, peneliti memperhatikan teori-teori terkait dengan prinsip integrasi teknologi dalam pembelajaran, khususnya dalam pembelajaran matematika, dan faktor-faktor yang memperhatikan keberhasilannya.

Selain berdampak positif, penggunana teknologi dalam pembelajaran dapat juga berdampak negatif jika tidak dilakukan dengan tepat guna. Terkait dengan hal ini, Putrawangsa \& Hasanah (2018) menegaskan bahwa prinsip dasar dalam penggunaan teknologi digital dalam pembelajaran, khususnya dalam pembelajaran matematika, adalah teknologi tidak digunakan sebagai pengganti penggunaan pemahaman konseptual dan intuisi bermatematika, akan tetapi sebaliknya teknologi berperan untuk meningkatkan pemahaman konseptual siswa tentang ide matematika dan juga mengembangkan kemampuan intuisi siswa dalam bermatematika.

Lebih lanjut, Putrawangsa \& Hasanah (2018) memaparkan bahwa terdapat 
tiga fungsi dedaktik dari teknologi dalam pembelajaran matematika, yaitu: Technology for doing mathematics, yaitu teknologi digital yang berfungsi sebagai alternatif alat pengganti media kertas dan pensil untuk melakukan kegiatan bermatematika, Technology for practicing skills, yaitu teknologi digital yang berfungsi sebagai lingkungan belajar untuk mengasah keterampilan matematika tertentu, Technology for developing conceptual understanding, yaitu teknologi digital yang berfungsi sebagai lingkungan belajar untuk mengembangkan pemahaman konseptual tentang matematika. Dari ketiga fungsi dedaktik tersebut, technology for developing conceptual understanding adalah ekspektasi yang paling diharapkan dari integrasi teknologi dalam pembelajaran matematika. Hal ini disebabkan karena matematika dipandang sebagai sistem pengetahuan yang dibangun melalui suatu proses konstruksi pengetahuan dan pemahaman yang didapatkan dari pengalaman hidup, termasuk di dalamnya adalah pengalaman belajar.

Ada tiga faktor yang perlu diperhatikan terkait dengan pengemabngan dan integrasi teknologi digital dalam pembelajaran matematika, yaitu: faktor desain rancangan teknologi, faktor peranan guru dalam penerapan teknologi tersebut, dan faktor konteks pendidikan dimana teknologi tersebut diterapkan (Putrawangsa \& Hasanah, 2018).

\section{METODE PENELITIAN}

Jenis penelitian ini adalah penelitian dan pengembangan (R\&D). Prosedur pengembangan yang digunakan adalah penelitian ADDIE yang merupakan singkatan dari Analysis, Design, Development or Production, Implementation or Delivery and Evaluations. Hasil penelitian dan pengembangan dari tiap tahapan dilakukan evaluasi. Tahap-tahap penelitian dan pengembangan ditunjukan pada diagram pada Gambar 1.

Tekhnik Pengumpulan data yang dilakukan yaitu dengan wawancara dan penyebaran angket skala likert dengan 4 jawaban. Penskoran yang digunakan dalam penilaian validasi ahli dapat dilihat pada Table 1. 


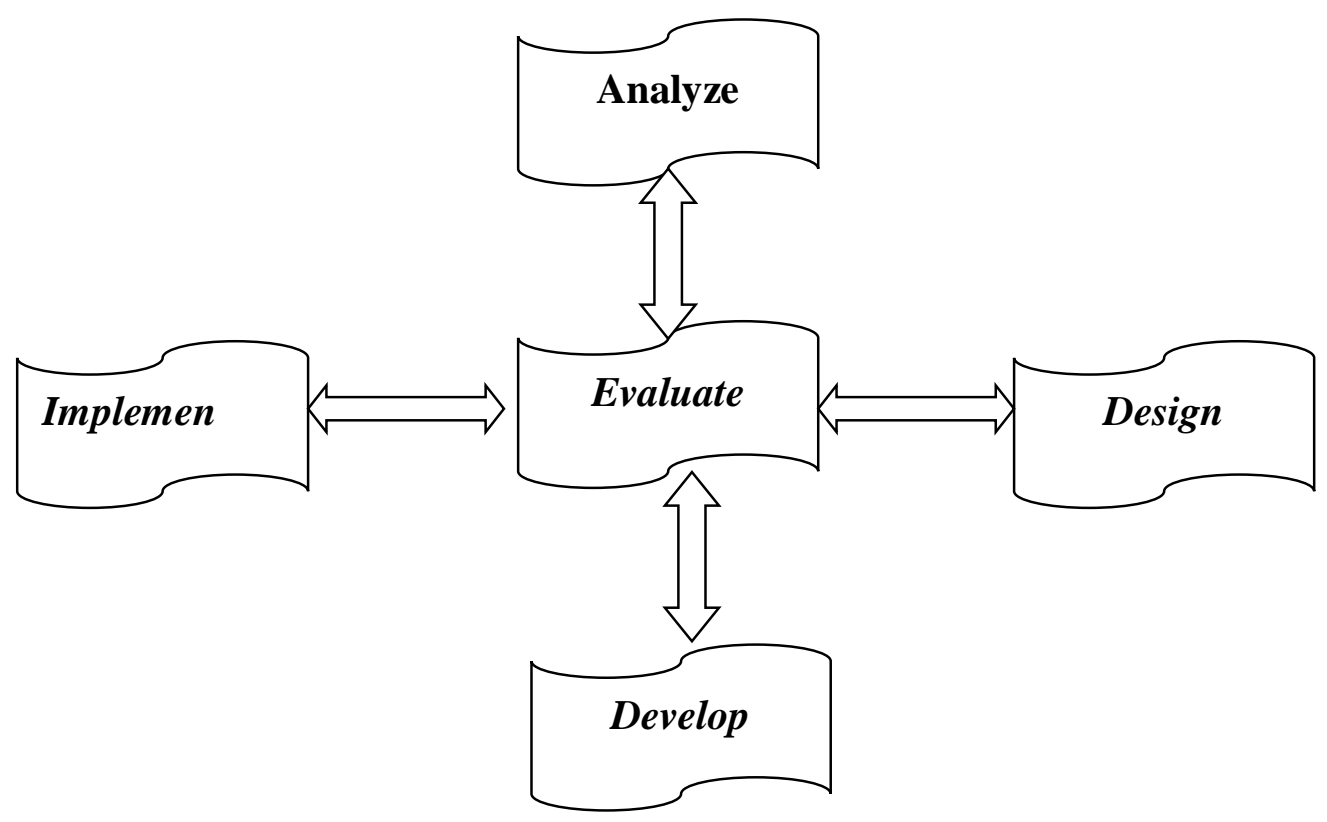

Gambar 1

Diagram Tahapan Model ADDIE

Tabel 1

Skor Penilaian Validasi Ahli Dimodifikasi

\begin{tabular}{cl}
\hline Skor & Pilihan Jawaban Kelayakan \\
\hline 4 & Sangat Setuju \\
3 & Setuju \\
2 & Kurang Setuju \\
1 & Tidak Setuju \\
\hline
\end{tabular}

Sedangkan penskoran uji kemenarikan produk dapat dilihat pada Tabel 2.

Tabel 2

Skor Penilaian Uji Coba dimodifikasi

\begin{tabular}{cl}
\hline Skor & Pilihan Jawaban Kelayakan \\
\hline 4 & Sangat Setuju \\
3 & Setuju \\
2 & Kurang Setuju \\
1 & Tidak Setuju \\
\hline
\end{tabular}

Skor penilaian total dalam analisa data dapat dicari dengan rumus berikut :

$$
\bar{x}=\frac{\sum_{i=1}^{n} x_{i}}{n}
$$


dengan:

$$
x_{i}=\frac{\text { jumlah skor }}{\text { Skor maks }} \times 4
$$

Keterangan : $\quad \bar{x}=$ rata - rata akhir

$x_{i}=$ nilai uji operasional angket tiap siswa

$n$ = banyaknya siswa yang mengisi angket

Dalam pengkonversian skor kelayakan dan kemenarikan produk, digunakan pedoman sebagai berikut :

Pengkonversian Skor Kelayakan Produk

Tabel 3

Kriteria Validasi (dimodifikasi)

\begin{tabular}{cll}
\hline Skor Kualitas & \multicolumn{1}{c}{ Kriteria } & \multicolumn{1}{c}{ Keterayakan } \\
\hline $3,26<\overline{\mathrm{x}} \leq 4,00$ & Valid & Tidak Revisi \\
$2,51<\mathrm{x} \leq 3,26$ & Cukup Valid & Revisi sebagian \\
$1,76<\overline{\mathrm{x}} \leq 2,51$ & Kurang Valid & Revisi sebagian \& pengkajian ulang \\
$1,00<\overline{\mathrm{x}} \leq 1,76$ & Tidak Valid & Revisi Total \\
\hline
\end{tabular}

Pengkonversian skor uji coba produk

Tabel 4

Kriteria untuk Uji Kemenarikan (dimodifikasi)

\begin{tabular}{cl}
\hline Skor Kualitas & \multicolumn{1}{c}{$\begin{array}{c}\text { Pertanyaan Kualitas Aspek } \\
\text { Kemenarikan }\end{array}$} \\
\hline $3,26<\bar{x} \leq 4,00$ & Sangat Menarik \\
$2,51<\bar{x} \leq 3,26$ & Menarik \\
$1,76<\bar{x} \leq 2,51$ & Kurang Menarik \\
$1,00<\bar{x} \leq 1,76$ & Sangat Kurang Menarik \\
\hline
\end{tabular}

\section{HASIL DAN PEMBAHASAN}

Tahap pertama dilakukan Analyze, dapat diketahui bahwa dalam proses pembelajaran di kelas guru masih menggunakan metode ceramah dan hanya memanfaatkan buku paket yang sudah disediakan oleh pemerintah di perpustakaan sekolah sebagai bahan ajar. Sementara kemampuan peserta didik dalam memahami konsep dimensi ruang masih rendah, bahkan terdapat peserta didik yang menganggap bangun ruang sebagai bangun datar. Pemilihan aplikasi sebagai pendukung dalam pembuatan media pembelajaran yang dikembangkan dikarenakan perkembangan teknologi, sehingga 
Handayani, H., Putra, F., \& Yetri, Y. (2018). PENGEMBANGAN MEDIA PEMBELAJARAN BERBASIS MACROMEDIA

FLASH. Jurnal Tatsqif, 16(2). Retrieved from http://journal.uinmataram.ac.id/

index.php/tatsqif/article/view/160

menyebabkan penggunaan media pembelajaran yang paling tepat adalah media audio visual. Media pembelajaran berupa flash ini dapat digunakan sebagai alat bantu mengajar pada berbagai bidang studi, karena media audio visual merupakan media yang memiliki unsur gerakan dan suara. Pembelajaran matematika menggunakan media pembelajaran sangat bermanfaat untuk merangsang penglihatan dan gaya gerak peserta didik. Selain itu dengan menggunakan media pembelajaran bisa menjadi sebuah interaksi komunikasi antara pendidik dan peserta didik melalui media yang digunakan (Masykur, Nofrizal, \& Syazali, 2017).

Selanjutnya dilakukan Evaluation pada tahap Analyze. Berdasarkan analisis kurikulum, analisis karakteristik peserta didik, dan analisis teknologi, maka peneliti akan mengembangkan media flash pembelajaran yang sesuai dengan Kurikulum Tingkat Satuan Pendidikan yang membahas materi kubus dan balok. Media video pembelajaran tersebut dibuat untuk mengatasi permasalahan yang ada dan bertujuan untuk meminimalisir asumsi-asumsi peserta didik bahwa matematika itu membosankan.

Tahap kedua dilakukan Design terkait pengembangan media ini. Media yang akan dikembangkan yaitu media pembelajaran berbasis macromedia flash. Dalam tahap perancangan ini ada beberapa langkah yang dipersiapkan terkait pengembangan media pembelajaran berbasis macromedia flash pada materi kubus dan balok meliputi penyusunan awal yaitu dipersiapkan sebuah aplikasi Macromedia Flash. Tahap perancangan juga dikumpulkan SK dan KD serta tujuan yang harus dicapai pada materi kubus dan balok. Setelah itu mendapatkan materi pokok bahasan kubus dan balok sebagai bahan yang akan dipindahkan pada media pembelajaran dari sumber yang ada yaitu perpustakaan. Selain perancangan media, penulis juga mempersiapkan angket penilaian kelayakan para ahli dan kemenarikan peserta didik terkait media yang dikembangakan.

Setelah dilakukan Evaluation pada tahap Design. Kerangka dalam media ini meliputi bagian intro (pembuka), bagian isi (materi) dan bagian penutup. 
Handayani, H., Putra, F., \& Yetri, Y. (2018). PENGEMBANGAN MEDIA PEMBELAJARAN BERBASIS MACROMEDIA FLASH. Jurnal Tatsqif, 16(2). Retrieved from http://journal.uinmataram.ac.id/ index.php/tatsqif/article/view/160

Materi pada media ini disusun berdasarkan Standar Kompetensi dan Kompetensi Dasar yang telah ditetapkan. Materi yang dimuat dalam media ini diambil buku paket kelas VIII dan dari berbagai referensi. Pembuatan media pembelajaran ini mengunakan Macromedia Flash.

Tahap ketiga dilakukan Development, kemudian dilakukan pembuatan media pembelajaran yang akan digunakan dalam proses pembelajaran berdasarkan design pada tahap sebelumnya. Media Pembelajaran ini meliputi:

a. Bagian intro (pembuka)

Tampilan bagian intro dapat dilihat pada Gambar 2, Gambar 3.

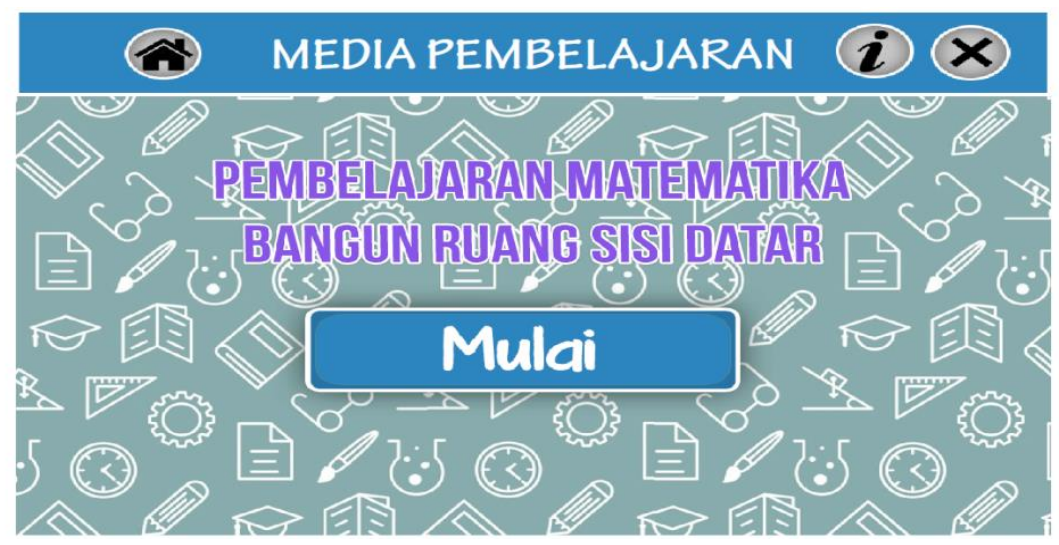

Gambar 2. Tampilan intro pada slide pertama

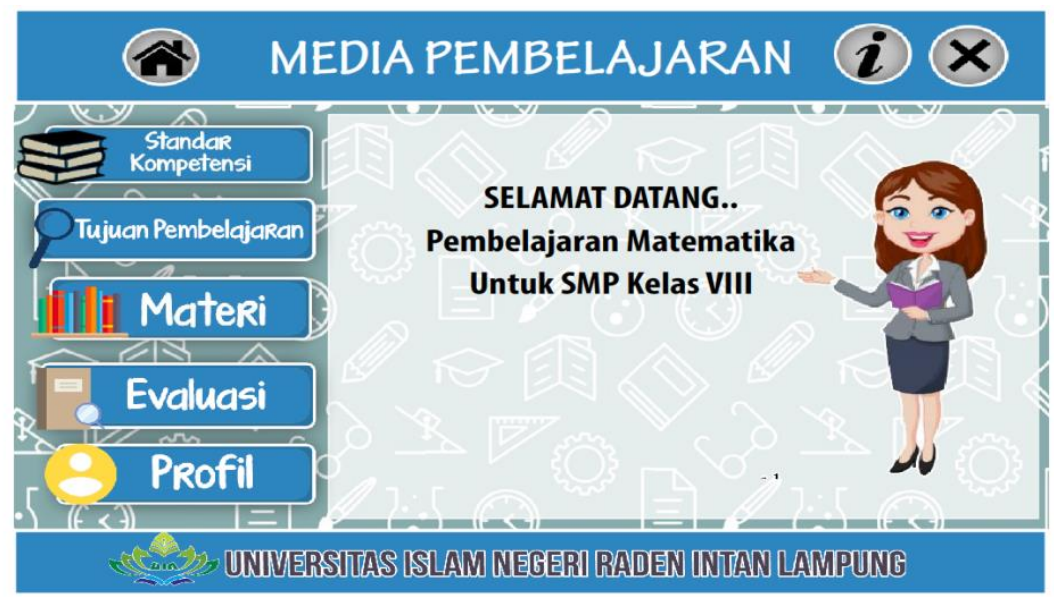

Gambar 3. Tampilan intro pada slide kedua

b. Bagian Isi (Materi)

Salah satu tampilan pada bagian isi (materi) dapat dilihat pada gambar 4 . 


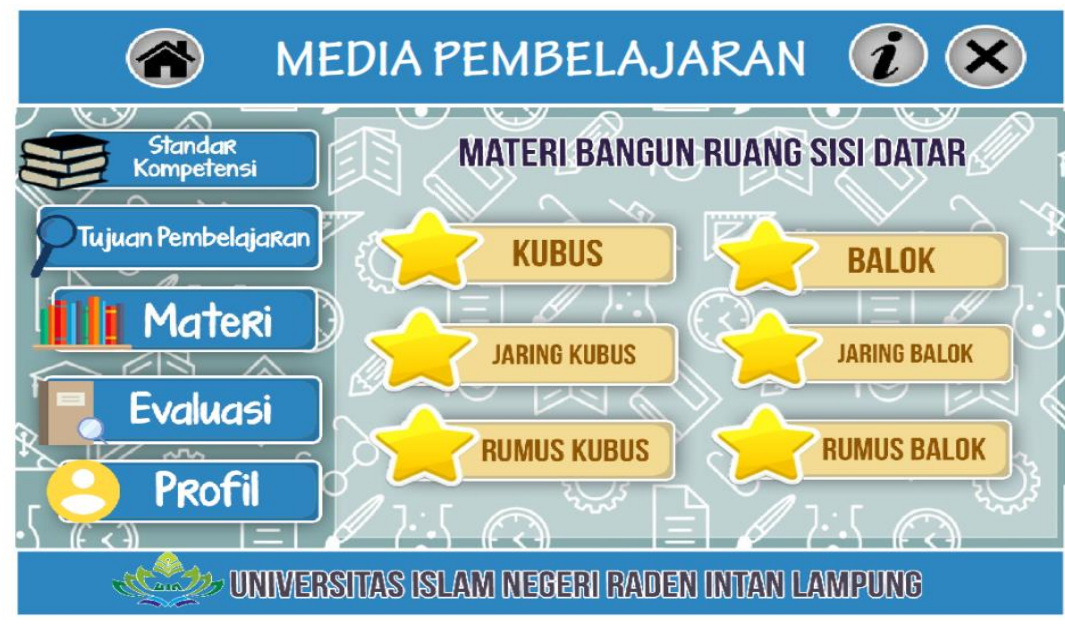

Gambar 5. Tampilan Materi Kubus dan balok

Setelah proses pembuatan media ini selesai, media ini dilakukan review oleh para ahli dan praktisi pendidikan yang akan menilai kualitas media. Dalam angket tersebut disediakan pula bagian isian untuk memberi komentar dan saran perbaikan. Dari hasil pengisisan angket tersebut akan diperoleh saran untuk melakukan revisi terhadap media. Tujuan dilakukan validasi adalah untuk memperoleh kritik dan masukan guna kesempurnaan video pembelajaran yang dihasilkan.

\section{Validasi Tahap 1}

a) Hasil Penilaian Validasi Ahli Materi

Hasil validasi tahap 1 oleh Ahli materi memperoleh nilai sebagai berikut: pada aspek kesesuaian materi diperoleh nilai rata-rata 2,9 dengan kriteria “ Cukup Valid". Aspek kesesuaian evaluasi diperoleh nilai rata-rata 2,8 dengan kriteria "Cukup Valid". Masukan dari Ahli materi yaitu: sesuaikan animasi dengan gambar, perjelas cara menemukan rumus luas permukaan kubus dan balok, tambahkan contoh soal pada submateri.

b) Hasil Penilaian Validasi Ahli Media

Hasil penilaian validasi tahap I oleh Ahli media memperoleh nilai sebagai berikut: pada aspek efisiensi media diperoleh nilai rata-rata sebesar 3 dengan kriteria " Cukup Valid”. Aspek fungsi tombol diperoleh nilai rata-rata sebesar 2,3 dengan kriteria "Kurang Valid". Aspek grafis diperoleh nilai rata-rata 2,7 
dengan kriteria "Cukup Valid". Masukan dari ahli media yaitu: suara musik dikecilkan sehingga suara pemateri terdengar jelas, menghilangkan efek warna kuning pada gambar tampilan awal, dan menambahkan latihan soal diluar dari media.

c) Hasil Penilaian Validasi Ahli Bahasa

Hasil penilaian validasi oleh Ahli bahasa memperoleh nilai sebagai berikut: pada aspek kebahasaan diperoleh nilai rata-rata sebesar 4 dengan kriteria "Valid". Menurut Ahli Bahasa penggunaan bahasa pada media pembelajaran tersebut sudah baik dan penulisan pada materi sudah sesuai dengan aturan EYD oleh karena itu tidak ada masukan-masukan untuk perbaikan media.

Setelah dilakukan review oleh para ahli, maka dilanjutkan dengan revisi sesuai dengan masukan-masukan para ahli. Ahli materi menyarankan untuk memperbaiki gambar kubus dan balok, menyesuaikan keluarnya animasi dengan gambar, dan memperjelas cara menemukan rumus luas permukaan kubus dan balok. Perbaikan yang dilakukan diantaranya pada Gambar 5 dan Gambar 6.

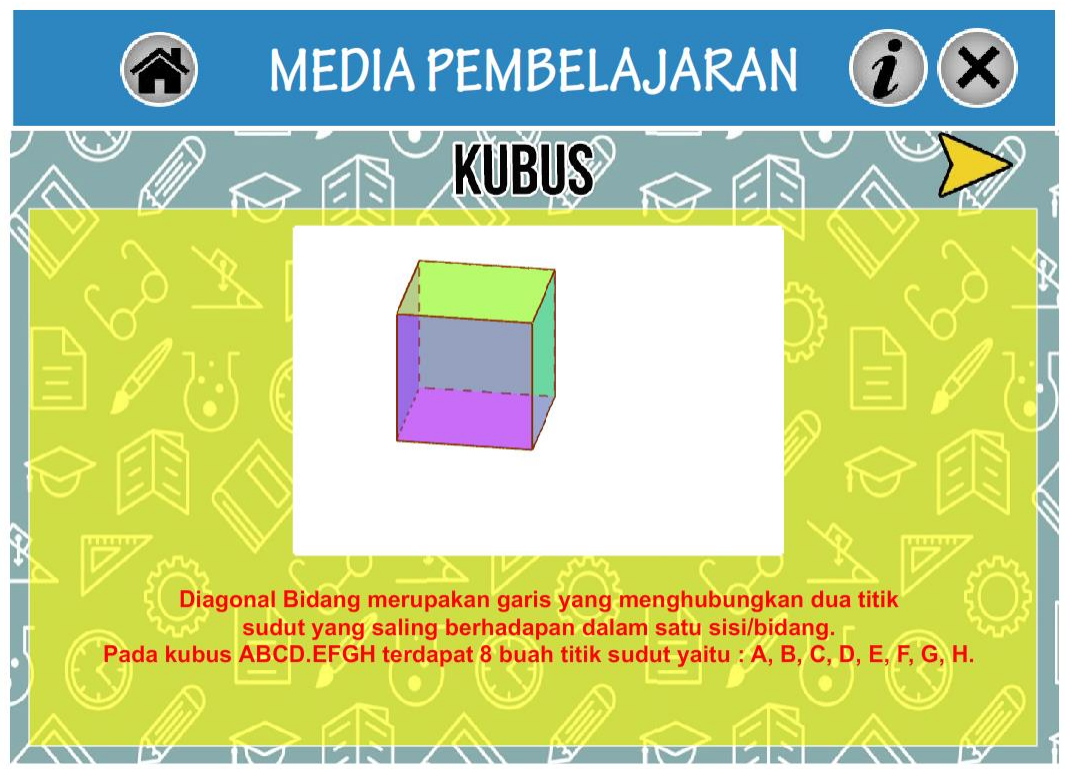

Gambar 5. Materi kubus sebelum direvisi 


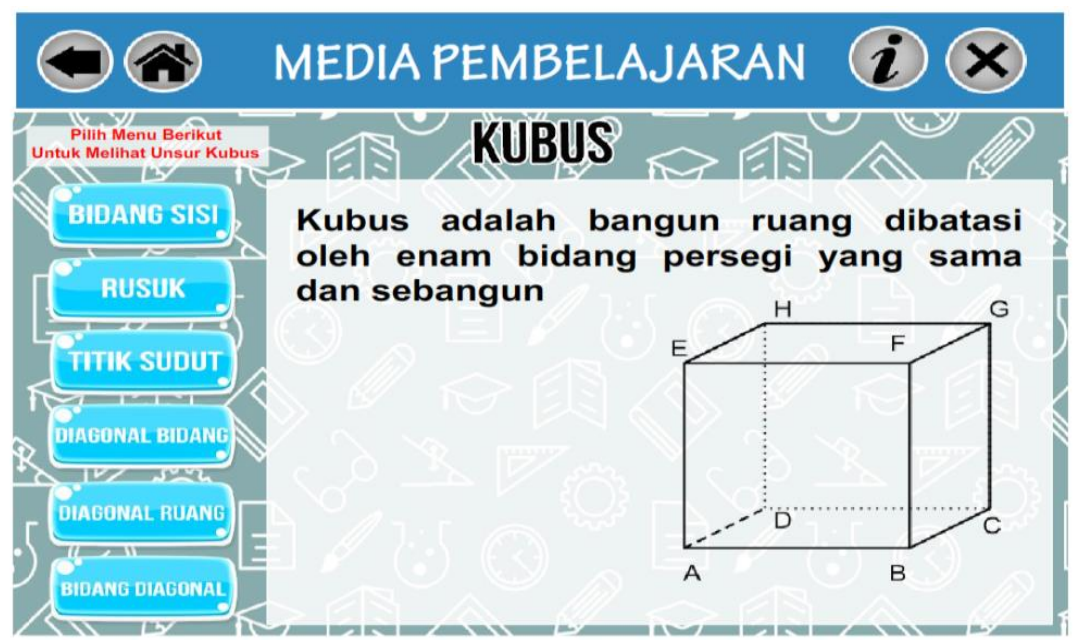

Gambar 6. Materi kubus sesudah direvisi

Setelah media direvisi, kemudian dilakukan validasi tahap 2 oleh para ahli.

2. Validasi tahap 2

a) Hasil Penilaian Validasi Ahli Materi

Hasil validasi Ahli materi memperoleh nilai sebagai berikut: pada aspek kesesuaian materi diperoleh nilai rata-rata 3,4 dengan kriteria "Valid". Aspek kesesuaian evaluasi diperoleh nilai rata-rata 3,7 dengan kriteria "Valid". Hasil penilaian validasi materi tahap 1 mengalami peningkatan pada penilaian validasi materi tahap 2. Perbandingan validasi materi tahap 1 dan tahap 2 dapat dilihat pada gambar 7.

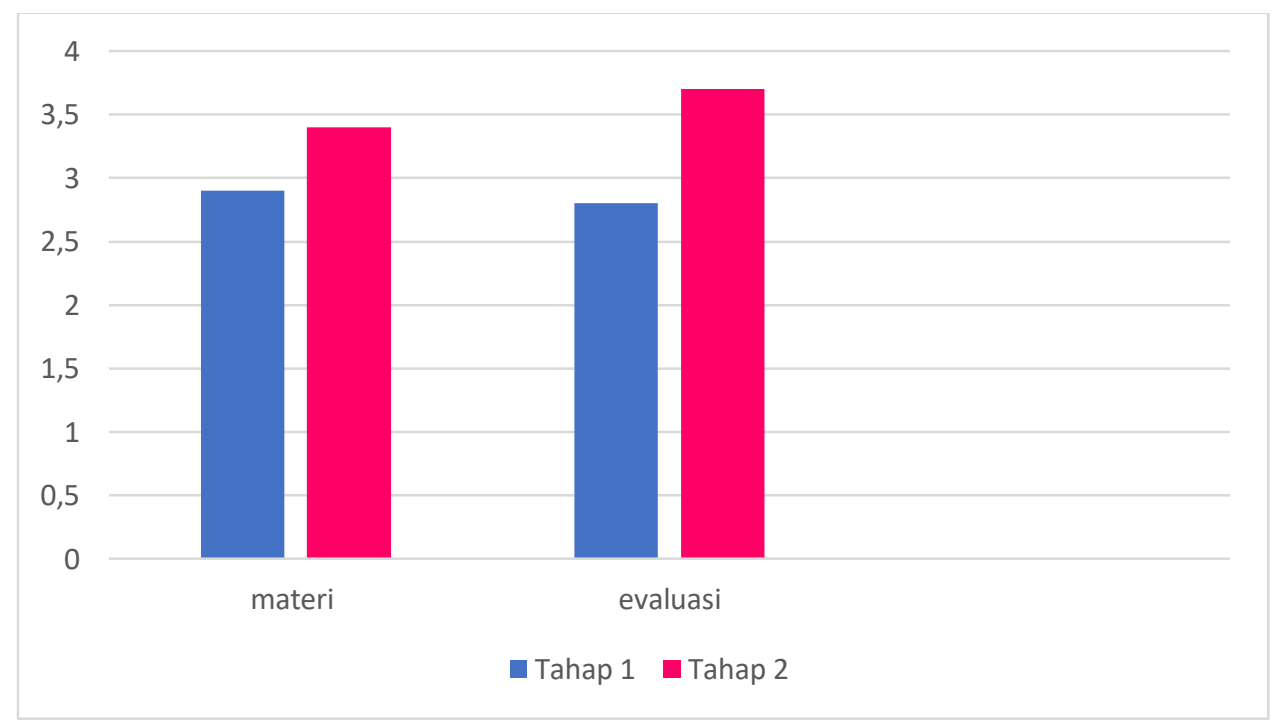

Grafik 1. Perbandingan validasi materi tahap 1 dan tahap 2 


\section{b) Hasil Penilaian Validasi Ahli Media}

Hasil validasi Ahli media memperoleh nilai sebagai berikut: pada aspek efisiensi media diperoleh nilai rata-rata sebesar 3,3 dengan kriteria "Valid". Aspek fungsi tombol diperoleh nilai rata-rata sebesar 3,3 dengan kriteria "Valid". Aspek grafis diperoleh nilai rata-rata 3,4 dengan kriteria "Valid". Hasil penilaian validasi media tahap 1 mengalami peningkatan pada penilaian validasi media tahap 2. Perbandingan validasi media tahap 1 dan tahap 2 dapat dilihat pada gambar 8 .

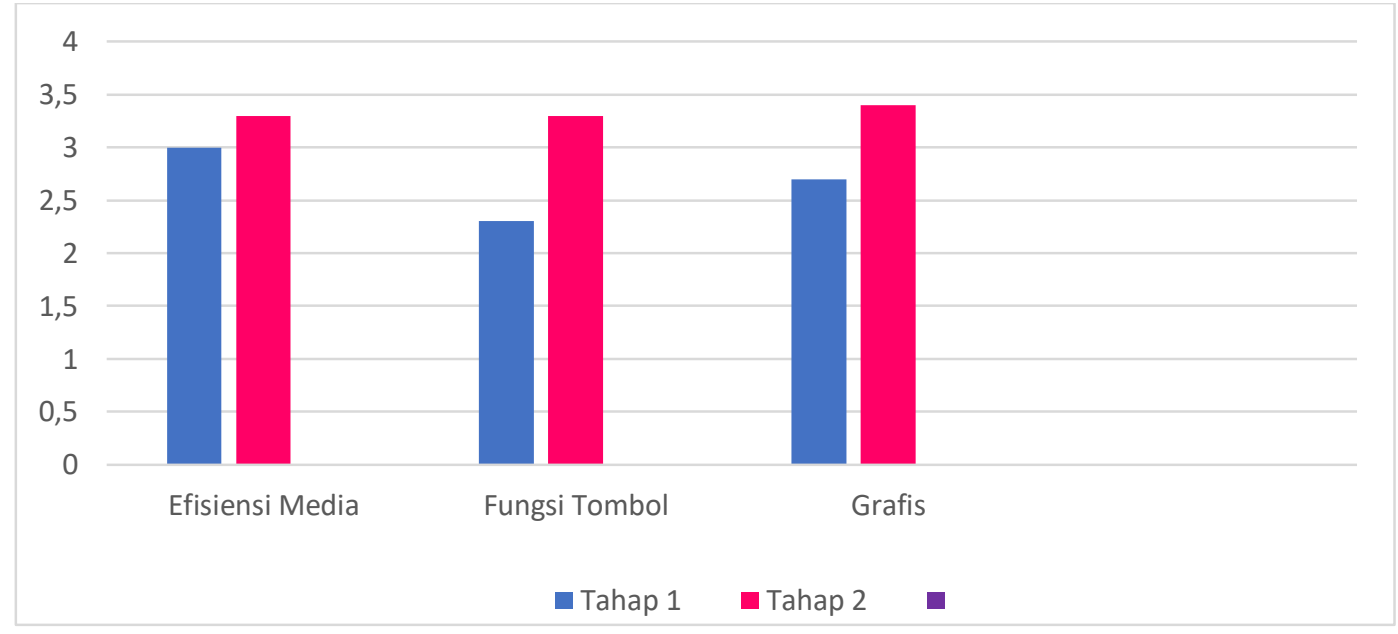

Grafik 2. Perbandingan validasi media tahap 1 dan tahap 2

c) Hasil Penilaian Validasi Ahli Bahasa

Penilaian angket validasi oleh ahli bahasa hanya dilakukan 1 tahap, karena menurut beliau penggunaan bahasa pada media pembelajaran tersebut sudah baik dan penulisan pada materi sudah sesuai dengan aturan EYD.

Setelah dilakukan Evaluation berdasarkan penilaian yang telah diperoleh, dapat diketahui bahwa media yang dikembangkan sudah dalam kategori menarik dari segi isi atau materi, tampilan serta bahasa sehingga media dapat dilanjutkan pada tahapan implementation untuk mengetahui respon yang diberikan oleh peserta didik.

Tahap Selanjutnya yaitu Implementation, setelah media pembelajaran yang telah dikembangkan serta telah dinyatakan valid dan layak diuji cobakan 
tanpa revisi oleh para ahli, selanjutnya media pembelajaran diujicobakan kepada responden. Uji coba ini dimaksudkan untuk mendapatkan informasi mengenai respon peserta didik terhadap media pembelajaran yang telah dikembangkan. Responden pada ujicoba lapangan ini dilakukan dalam 2 tahapan yaitu uji coba kelompok kecil yang terdiri dari 10 responden dan uji coba lapangan yang terdiri dari 30 responden. Hasil uji coba respon kemenarikan peserta didik dapat dilihat pada Tabel. 5 dan Tabel 6.

Tabel 5

Hasil uji coba skala kecil

\begin{tabular}{cccc}
\hline Responden & Jumlah Skor & Skor kelayakan & Kriteria \\
\hline 1 & 47 & 3,61 & Sangat menarik \\
2 & 49 & 3,76 & Sangat menarik \\
3 & 48 & 3,69 & Sangat Menarik \\
4 & 48 & 3,69 & Sangat menarik \\
5 & 48 & 3,69 & Sangat Menarik \\
6 & 48 & 3,69 & Sangat menarik \\
7 & 46 & 3,53 & Sangat menarik \\
8 & 49 & 3,76 & Sangat menarik \\
9 & 47 & 3,61 & Sangat menarik \\
10 & 50 & 3,84 & Sangat menarik \\
Jumlah & $\mathbf{4 8 0}$ & $\mathbf{3 6 , 8 7}$ & $\overline{\boldsymbol{x}}=\mathbf{3 , 6 8}$ \\
\hline
\end{tabular}

Tabel 6

Hasil uji coba skala besar

\begin{tabular}{cccc}
\hline Responden & Jumlah Skor & Skor kelayakan & Kategori \\
\hline 1 & 48 & 3,69 & Sangat Menarik \\
2 & 40 & 3,07 & Menarik \\
3 & 52 & 4 & Sangat Menarik \\
4 & 44 & 3,38 & Sangat Menarik \\
5 & 48 & 3,69 & Sangat Menarik \\
6 & 46 & 3,53 & Sangat Menarik \\
7 & 48 & 3,69 & Menarik \\
8 & 50 & 3,84 & Sangat Menarik \\
9 & 42 & 3,23 & Menarik \\
10 & 46 & 3,53 & Sangat Menarik \\
11 & 39 & 3 & Menarik \\
12 & 48 & 3,69 & Sangat Menarik \\
13 & 48 & 3,69 & Sangat Menarik \\
14 & 43 & 3,30 & Sangat Menarik \\
15 & 46 & 3,53 & Sangat Menarik
\end{tabular}




\begin{tabular}{cccc}
\hline Responden & Jumlah Skor & Skor kelayakan & Kategori \\
\hline 16 & 47 & 3,61 & Sangat Menarik \\
17 & 47 & 3,61 & Sangat Menarik \\
18 & 48 & 3,69 & Sangat Menarik \\
19 & 43 & 3,30 & Sangat Menarik \\
20 & 40 & 3,07 & Menarik \\
21 & 46 & 3,53 & Sangat Menarik \\
22 & 46 & 3,53 & Sangat Menarik \\
23 & 47 & 3,61 & Sangat Menarik \\
24 & 47 & 3,61 & Sangat Menarik \\
25 & 45 & 3,39 & Sangat Menarik \\
26 & 48 & 3,69 & Sangat Menarik \\
27 & 46 & 3,53 & Sangat Menarik \\
28 & 45 & 3,39 & Sangat Menarik \\
29 & 48 & 3,69 & Sangat Menarik \\
30 & 40 & 3,07 & Menarik \\
Jumlah & 1.371 & 97,96 & $\overline{\boldsymbol{x}}=\mathbf{3}, \mathbf{5 1}$ \\
\hline
\end{tabular}

Selanjutnya dilakukan Evaluation berdasarkan data yang ditampilkan dalam tabel 1 dan 2, tingkat kemenarikan produk pada uji coba kelompok kecil memperoleh skor rata-rata 3,68 dengan kriteria "Sangat Menarik" dan uji coba kelompok besar mencapai skor rata-rata 3,40 dengan kriteria "Sangat Menarik". Dalam hal ini menunjukkan bahwa media pembelajaran yang telah dibuat layak untuk digunakan sebagai media pembelajaran pada materi kubus dan balok. Hasil penelitian ini sama dengan hasil penelitian sebelumnya bahwa mediapembelajaran mendapatkan respon yang sangat baik dan sangat menarik oleh peserta didik, karena memahami materi lebih mudah dengan contoh yang tampak oleh mata (Purwanti, 2015; Putri, Parmiti, \& Dr. I Komang Sudarma, 2017; Rozie, 2013).

\section{KESIMPULAN DAN SARAN}

Berdasarkan hasil penelitian yang telah dipaparkan sebelumnya maka ditarik kesimpulan bahwa penelitian ini menghasil media pembelajaran berbasis macromedia flash dalam pembelajaran matematika pada pokok bahasan kubus dan balok yang dikembangkan dengan metode ADDIE. Hasil validasi oleh hasil ahli materi memperoleh skor rata-rata 3,5, validasi oleh ahli 
Handayani, H., Putra, F., \& Yetri, Y. (2018). PENGEMBANGAN MEDIA PEMBELAJARAN BERBASIS MACROMEDIA

FLASH. Jurnal Tatsqif, 16(2). Retrieved from http://journal.uinmataram.ac.id/

index.php/tatsqif/article/view/160

media 3,3 serta valiadasi oleh ahli bahasa 4 masing-masing hasil pada kriteria sangat layak. Sedangkan hasil uji coba produk pada uji skala kecil memperoleh skor rata-rata 3,68 dan uji skala besar memperoleh skor rata-rata 3,51 dengan masing-masing kriteria sangat menarik. Berdasarkan hal ini maka media pembelajaran berbasis macromedia flash layak dignakan sebagai media pembelajaran matematika.

Saran-saran yang dapat disampaikan berdasarkan hasil penelitian ini adalah: perlu ditambahkan contoh soal dan evaluasi soal yang lebih beragam. Dari hasil penelitian ini pembaca diharapkan dapat terinspirasi untuk melakukan eksperimen atau penelitian tindakan kelas untuk mengetahui pengaruhnya terhadap hasil belajar.

\section{DAFTAR PUSTAKA}

Amalana, H. (2015). Pengaruh Model Pembelajaran Quantum Teaching Berbantuan Modul QT-Bilingual Terhadap Hasil Belajar Siswa. Jurnal Inovasi Pendidikan Kimia, 7(2).

Febriana, L. C. (2014). Pengembangan Lembar Kerja Siswa (LKS) Fisika Materi Tekanan Mencakup Ranah Kognitif, Afektif, dan Psikomotor Sesuai Kurikulum 2013 Untuk Siswa SMP/MTs. SKRIPSI Jurusan FisikaFakultas MIPA UM.

Hendra, F. (2017). Analisis Tingkat Kematangan Industri Komponen Otomotif Di Indonesia. Jurnal Mesin Teknologi, 11(1), 38-48.

Khairani, M., \& Febrinal, D. (2016). Pengembangan Media Pembelajaran Dalam Bentuk Macromedia Flash Materi Tabung Untuk SMP Kelas IX. Jurnal Ipteks Terapan, 10(2), 95-102.

Lestari, N. A., \& Istiqomah, I. (2017). Pengembangan Multimedia Pembelajaran Kurikulum 2013 Pada Pokok Bahasan Trigonometri Di Smk. Union: Jurnal Ilmiah Pendidikan Matematika, 5(3).

Masykur, R., Nofrizal, N., \& Syazali, M. (2017). Pengembangan Media Pembelajaran Matematika dengan Macromedia Flash. Al-Jabar : Jurnal Pendidikan Matematika, 8(2), 177-186.

Netriwati, \& Sri Lena, M. (2017). Media Pembelajaran Matematika. Permata Net. 
Nugroho, A. A., Putra, R. W. Y., Putra, F. G., \& Syazali, M. (2017). Pengembangan Blog Sebagai Media Pembelajaran Matematika. Al-Jabar: Jurnal Pendidikan Matematika, 8(2), 197-204.

Purwanti, B. (2015). Pengembangan Media Video Pembelajaran Matematika dengan Model Assure. Jurnal Kebijakan dan Pengembangan Pendidikan, $3(1)$.

Putra, F. G. (2016). Pengaruh Model Pembelajaran Reflektif dengan Pendekatan Matematika Realistik Bernuansa Keislaman terhadap Kemampuan Komunikasi Matematis. Al-Jabar: Jurnal Pendidikan Matematika, 7(2), 203-210.

Putrawangsa, S., \& Hasanah, U. (2018). INTEGRASI TEKNOLOGI DIGITAL DALAM PEMBELAJARAN DI ERA INDUSTRI 4.0. Jurnal Tatsqif, 16(1), 42-54.

Retrieved from http://journal.uinmataram.ac.id/index.php/tatsqif/article/view/203

Rozie, F. (2013). Pengembangan Media Video Pembelajaran Daur Air untuk Meningkatkan Proses dan Hasil Belajar IPA Siswa SD. Jurnal Pendidikan Sains, 1(4), 413-424.

Setiawan, D. C., Corebima, A. D., \& Zubaidah, S. (2013). Pengaruh Strategi Pembelajaran Reciprocal Teaching (RT) Dipadu Pemberdayaan Berpikir Melalui Pertanyaan (PBMP) terhadap Kemampuan Metakognitif Biologi Siswa SMA Islam Al-Ma'arif Singosari Malang. Dalam Proceeding Biology Education Conference: Biology, Science, Enviromental, and Learning (Vol. 10, hlm. 195-201). 